\title{
La prohibición del comercio entre Nueva España y Perú de 1634: génesis de una real cédula a través de la coyuntura histórica de la monarquía hispánica
}

\section{The Ban of Trade between New Spain and Peru: genesis of a real cédula throughout the historic conjunction of the Spanish Monarchy}

BRUNO DE LA SERNA NASSER

Universidad Nacional Autónoma de México / Universidad de Sevilla brunodelaserna@comunidad.unam.mx

\section{RESUMEN}

Este artículo analiza desde una perspectiva transnacional la coyuntura histórica que provocó que Felipe IV decretara la prohibición total del comercio entre los virreinatos de Nueva España y Perú en 1634. Ello lleva a explicar el debate llevado a cabo por variados personajes e instituciones en diversos espacios geográficos a lo largo y ancho de la Monarquia Hispánica, el cual se relaciona con la situación interna de sus diversos componentes y el contexto internacional por el que se atravesaba en los convulsos años previos. A través de esto, se pondera hasta qué punto era una monarquia policéntrica.

Palabras clave: Nueva España, Perú, comercio, cédula, corporaciones, prohibición.

\section{ABSTRACT}

This paper discusses, from a transnational point of view, the historical context that led Philip IV to decree a total prohibition of trade between the viceroyalties of New Spain and Peru in 1634. It revisits the discussion among diverse figures and institutions across the Empire, taking into consideration the complex 
domestic and international developments in the previous years; and, in this light, ponders to what extent Imperial Spain was a polycentric monarchy.

Keywords: New Spain, Peru, trade, cédula, probibition

1 comercio entre Nueva España y Perú se dio prácticamente desde
que se establecieron los virreinatos en la primera mitad del siglo XVI, pero a partir de que fue inaugurada la nao de China en 1573, el intercambio entre ambos virreinatos se intensificó de forma dramática, generando inmensas cantidades de dinero a consecuencia de la introducción de los codiciados géneros asiáticos. De tal suerte, no tardaron en aparecer opositores a esos lucrativos tratos por el océano Pacífico, los cuales se apoyaron sobre dos pilares fundamentales. Primero, gracias al tráfico interindiano, los americanos se encontraban cada vez más abastecidos, por lo que iban perdiendo la necesidad de productos europeos, haciendo peligrar la, de por si escasa, producción castellana; así como el comercio trasatlántico que estaba en manos de los cargadores de Sevilla. Se temía, además, que la independencia económica pudiera derivar en una emancipación política. En segundo lugar, los americanos solo podían adquirir las mercancías de Oriente con plata, pues a los chinos apenas les hacían falta otros productos, por lo que, de la producción argentífera americana — sobre todo la peruana—, ahora se dirigía buena parte hacia el continente asiático sin pasar por España, que se había vuelto tan dependiente de ella. Conjuntamente, ambas razones parecían vaticinar la ruina de Castilla y, por ende, de la monarquía. ${ }^{1}$

Consecuentemente, inició un debate en el que participaron variadas corporaciones o particulares de diversos espacios geográficos a lo largo y ancho de aquella monarquía que se podría considerar policéntrica. Dichos actores se enfrascaron en pugnas por el control del mercado y en defensa de sus intereses individuales y los de sus centros, como podían

1 Ha habido grandes autores que han sentado las bases para el conocimiento del comercio intervirreinal así como para el tema del flujo de plata americana hacia Asia, aunque no hay espacio para mencionar a todos aquí, varios de ellos aparecen vertidos a lo largo del texto. 
ser Sevilla, México, Lima, Manila y, por supuesto, Madrid, pues, si bien la Corona actuaba como una especie de mediador, también necesitaba velar por el bienestar de su Real Hacienda. Aquella pugna duraría décadas, a través de las cuales, los que se oponían al trato por el Pacífico fueron persuadiendo a la Corona de que sus alegatos eran los que mejor se correspondían con la prosperidad de ella. Esta había renegado de cerrar por completo el comercio de Nueva Espańa con Filipinas por no abandonar al archipiélago y, con ello, la esperanza de que el catolicismo penetrara en Asia, pero, poco a poco, fue expidiendo cédulas que fueron limitando el trato por la Mar del Sur cada vez más hasta que, en 1634, se prohibió por completo el tráfico entre Acapulco y el Callao. ${ }^{2}$

La historiografía más clásica, ya mencionada, así como alguna de la más actual, ha estudiado muy bien este proceso de limitación gradual del comercio por el Pacífico desde una perspectiva de larga duración. ${ }^{3}$ Ello ha permitido comprender los procesos históricos que marcaron la temprana globalización. No obstante, si se analizan las cosas desde una escala más cercana, se pueden mirar detalles que a la distancia pasan desapercibidos, tal y como han mostrado varios autores que han escrito en lo que va del siglo XXI al profundizar mucho más en temas específicos. Hay que considerar que cada cédula emitida por la Corona lleva detrás condicionantes que pueden ser parte de un proceso largo, el cual, para el caso particular de esta, ya ha sido estudiado por la historiografía a grandes rasgos. Pero las cédulas también pueden encontrar su explicación en hechos, situaciones o necesidades mucho más inmediatas. Son producto de un contexto socio-económico-político que es examinado y criticado por ciertos actores, dando paso a un proceso administrativo —no carente de discusión— para su aprobación y despacho. ${ }^{4}$ Sus autores

${ }^{2}$ No tiene caso que se enlisten aquí todas esas cédulas que ya otros autores han reseñado anteriormente, igualmente pueden consultarse directamente en la Politica Indiana de Juan de Solórzano Pereira, o en la Recopilación de leyes de los reinos de Indias.

3 Bonialian $(2014,2019)$ tiene algunos de los trabajos más actuales acerca de estas temáticas desde perspectivas de larga duración, las cuales sientan bases maravillosas para que otros autores se aventuren a estudiar cosas más específicas.

${ }^{4}$ Un buen ejemplo de esto se puede ver en Alonso Álvarez (2016), con el debate alrededor de la primera cédula de limitaciones, expedida en 1593. 
intelectuales pueden provenir desde las esferas más altas, como los consejeros o los virreyes, o de simples arbitristas o memorialistas que podían o no ejercer un cargo.

Se partirá de la hipótesis de que la cédula versa sobre una ruta marítimacomercial específica que conectaba las puertas —Callao y Acapulco- de dos regiones más o menos definidas, pero esa ruta podía influir mucho más allá de sus áreas jurisdiccionales llegando a otras áreas del globo y, viceversa, hechos ocurridos en lugares muy lejanos podían afectar a esa ruta.

Considerando lo anterior, ¿qué pasa si, además de tomar en cuenta el largo proceso, se analiza la coyuntura que genera una cédula en particular desde su inmediatez, y, al mismo tiempo, se intenta conectarla con la globalidad de su contexto desde la perspectiva de la historia transnacional?5 Así se puede encontrar una suma trascendencia en hechos muy singulares, incluso muy lejanos, que pueden haber influido de manera determinante, ya fueran planeados o azarosos, incluso aquellos causados por la naturaleza; esos detalles que la historia de larga duración pasa por alto.

Eso es, a grandes rasgos, lo que aquí se intentará develar respecto de la cédula de $1634,{ }^{6}$ por lo que se centrará solamente en los años inmediatamente anteriores para explicar la ulterior coyuntura histórica, así como el proceso administrativo — hasta ahora desconocido - ${ }^{7}$ que determinó que Felipe IV tomara, finalmente, esa medida tan drástica. Antes de

5 En este sentido, claramente no se refiere al término contemporáneo de estado-nación, sino al concepto que se tenía en siglo XVII de un grupo de personas pertenecientes a una comunidad específica que se interesaban en el bienestar de la ciudad a la que pertenecían y de la región sobre la cuál ejercía jurisdicción. Si bien su preocupación principal era el bien común de su República urbana, ello siempre implicaba — o fingía hacerlo — el bien de la Monarquía. Al respecto, véanse Herrero Sánchez 2019 y Yun Casalilla 2019. El último autor ha explicado cómo sí se puede hablar de historia transnacional en la Edad Moderna. 6 Si bien, por obvias razones, muchos de los autores nombrados anteriormente han hecho mención en sus obras sobre la dicha cédula, la única que ha dedicado un artículo estrechamente relacionado a ella fue Suárez (2015). Es un gran trabajo que mira aquella coyuntura desde la perspectiva del consulado limeño, por lo que aquí se busca una visión complementaria desde otros espacios u otras corporaciones.

7 La única autora que, con algunos documentos de la British Library llegó a mencionar este proceso, muy superficialmente, fue García de los Arcos (1993), pero, de nuevo, se insiste en que no profundizó por ser un texto que abarca tres siglos. 
comenzar, baste decir que, para estos ańos, se encontraba vigente la cédula de 1620 que establecía que, del Callao a Acapulco, sólo podrían navegar dos navíos de 200 toneladas que podrían cargar 200 mil ducados de plata peruana para intercambiarlos por productos exclusivamente novohispanos, es decir, nada europeo ni asiático. ${ }^{8}$

\section{LA CRISIS DE LA MONARQUÍA DE FELIPE IV (I628-I632)}

Desde el ascenso de Felipe IV en 1621, asistido por el conde de Olivares, había impulsado una reforma interna de la monarquía y una recuperación de la reputación española en el plano internacional en defensa de la fe. Por ello continuó la intervención en la Guerra de los Treinta Años y reanudó la actividad bélica en Flandes. A pesar de las grandes victorias conseguidas, especialmente las de 1625, la monarquía se vio sumamente presionada y requirió cada vez más plata para financiar sus empresas. Ello evidenció que, a pesar de las cédulas expedidas, la producción y el comercio que las Indias llevaban a cabo entre sí había causado que perdieran la necesidad de muchos de los productos que antes importaban de la Península, mientras que Castilla atravesaba por una seria crisis de hambre e inflación derivada de sequías y de la acuñación de monedas de vellón. Además, esa desolada población tenía que cargar con altos impuestos pues sobre sus hombros recaían casi todos los gastos militares. Durante la transición de 1626 a 1627, el Conde duque había ideado el proyecto de la Unión de Armas, mediante el cual esperaba que todos los componentes de la monarquía cooperasen proporcionalmente a sus capacidades para sobrellevar los esfuerzos de guerra. No obstante, consagrar el proyecto llevaría tiempo y, asediado por las críticas a su régimen, buscó un éxito militar en el extranjero y convenció a Felipe IV de intervenir en el ducado de Mantua para evitar que este quedara en manos de un heredero francés, pretendiendo asegurar así el «camino español». Para financiar la campaña pidió un préstamo a los banqueros que ofreció pagar con la próxima flota que llegase de Indias. Pero para su

${ }^{8}$ Real Cédula. Madrid, 28 de marzo de1620, Archivo General de Indias [en adelante AGI], Lima, 571, L. 18, ff. 269-279. 
mala suerte, y de toda la monarquía, aquella fue la flota de Nueva España que, en septiembre de 1628, fue asaltada por Piet Heyn en Matanzas, donde los españoles huyeron sin resguardar el botín o al menos enviarlo al fondo del mar. ${ }^{9}$

Antes de recibir notificación de aquel funesto suceso, el virrey de Nueva España, que era el marqués de Cerralbo, intentaba implantar la Unión de Armas doblando el impuesto de la alcabala. ${ }^{10}$ Ello había provocado la oposición de los regidores del Cabildo, algunos de los cuales estaban ligados al comercio, como Juan Francisco de Vértiz, quien hizo un recuento de los aprietos que experimentaba el virreinato, entre los cuales mencionaba el escaso producto sacado de las minas y las numerosas cargas fiscales que debía sostener, las cuales sumaban cerca de $240 \mathrm{mil}$ pesos anuales tan solo de la ciudad de México. Esgrimía que la mayor parte de la plata se enviaba a Espańa o al socorro de Filipinas y que casi todos los beneficios que arrojaba el comercio eran absorbidos por la Real Hacienda. En suma, que si a ello se le aumentaban los $250 \mathrm{mil}$ ducados anuales que se solicitaban para la Unión, en México quedaría «sólo el sonido de la riqueza que ha ido a España» ${ }^{11}$ y el virreinato no tendría con qué espolear su economía, provocando su ruina. De tal suerte, opinaba que la única manera en que la Nueva España podría ser capaz de enviar toda esa plata al soberano sería si este permitiese el libre comercio con las Filipinas y el Perú, sin limitantes de cantidades o géneros, para que, «engrosándose por este camino, el reino tenga de dónde sacar algún fruto». ${ }^{12}$ La cuestión continuaba hasta que el 24 de

9 Domínguez Ortiz 1998; Parker 2006.

${ }^{10}$ Este año se embarcó el conde de Chinchón hacia el Perú, donde tomaría el puesto como nuevo virrey en enero de 1629. Previamente había ejercido como tesorero general de Aragón, donde había contribuido a la implantación de la Unión de Armas. Ahora era enviado a Perú con el mismo fin (Amadori 2011: 299).

${ }^{11}$ Acta del cabildo de México, 11 de noviembre de 1629, en Orozco y Espinosa 18991911, 26: 380 .

${ }^{12}$ Acta del cabildo de México, 11 de noviembre de 1629, en Orozco y Espinosa 18991911, 26: 380; Carta del virrey marqués de Cerralbo al rey. México, 14 de enero de 1629, AGI, México, 30, n. 10, ff. 49-52. Pero mientras este mexicano pedía aquello, otras personas alrededor del mundo solicitaban lo contrario: en Sudamérica, Juan Velázquez escribía que, a pesar de la prohibición, una enorme cantidad de sedas chinas continuaba 
noviembre llegó a México la noticia de que se había perdido la dichosa flota. ${ }^{13}$ Ello significaba un duro golpe para la economía virreinal y causó una profunda consternación, por lo que la discusión sobre la Unión se tuvo que dejar a un lado.

Durante el resto de 1628 no llegó ninguna flota a Espańa, generando tensión. El 9 de enero del siguiente año arribó Piet Heyn a La Haya con el trofeo y fue recibido como un héroe. ${ }^{14}$ Poco después tocó la Península la flota de Tierra Firme con la terrible noticia de haberse perdido la de Nueva España, provocando turbación a los comerciantes andaluces. Alcanzó Madrid el día 29, ${ }^{15}$ causando la ira de Felipe IV y Olivares. Los efectos del robo de la flota fueron casi inmediatos: corrió el pánico en Flandes al saberse que los neerlandeses se encontraban reforzados económica y anímicamente con el botín, y el frente del norte de Italia quedó atascado. Este se había concebido como una breve y contundente victoria, pero se convirtió en un largo y costoso asedio que desviaría recursos de otros frentes de batalla. ${ }^{16}$ El Consejo de Estado, apoyado por Ambrosio Spínola, autorizó a Isabel Clara Eugenia, gobernadora de los Países Bajos, a negociar con las Provincias Unidas y las consecuencias fueron exactamente las que Olivares temía: los holandeses aprovecharon la debilidad mostrada y pasaron a la ofensiva con gran ahínco. A su vez, Luis XIII de Francia lideró un ejército hacia Mantua y obligó a los españoles a levantar el sitio. ${ }^{17}$ Felipe IV cayó en depresión al pensar

llegando a Perú y Tierra Firme proveniente de Nueva España y que ello era impulsado por los virreyes, generales y justicias para su propio interés (Schurz 1918: 400); Duarte Gómez de Solís, portugués residente en Madrid, expresaba que la abundancia de reales de plata americanos en Asia procedentes de Filipinas había generado un alza de precios en los productos orientales que antes importaba Portugal mucho más baratos, provocando gran daño también a los consumidores castellanos (Valdés 1987: 111); y el gobernador de Filipinas exclamaba que el único dios que los chinos tenían era la plata, y la única religión que profesaban era la manera de conseguirla (Gordon y Morales 2017: 500).

${ }^{13}$ Acta del cabildo de México, 25 de agosto de 1628, en Orozco y Espinosa 1899-1911, 26: 335 .

${ }^{14}$ Lucena 1992: 142.

${ }^{15}$ Domínguez Ortiz 1998: 14.

${ }^{16}$ Chamorro 1998: 190; Parker 2003: 138.

${ }^{17}$ Elliott 1990: 161; Parker 2003: 140. 
que Dios estaba enojado con él por sus pecados, pues todo parecía irse a pique en su reinado. ${ }^{18}$

Por su parte, los comerciantes de Sevilla habían perdido las ganancias correspondientes de un año y tendrían que reponer los galeones perdidos, para lo cual habrían de incrementar la avería un 5\%. ${ }^{19}$ Además, las consecuencias de los reveses en ambos frentes recayeron sobre los mismos, pues el monarca no se compadeció de sus pérdidas y pidió 200 mil ducados para acompañar a la infanta María en su viaje a Barcelona, donde la despediría antes de su partida para casarse con el hijo del emperador Fernando II. Para Olivares ese enlace era prioritario para mantener lazos firmes con la otra rama de los Habsburgo, pero la Real Hacienda no podía asumir el gasto. ${ }^{20}$ No contento con ello, poco después, Felipe IV pidió un préstamo de un millón de ducados. El Consulado esgrimió que desde 1624 había hecho servicios por 1,600,000 ducados y sufrido pérdidas de 15 millones. El Consejo de Indias defendió al Consulado y le advirtió al rey que, con semejante pérdida, corría el riesgo de quedar destruido el comercio y, consecuentemente, segados importantes ingresos a la Corona. Pero el Consejo de Estado indicó que, de no tomarse esa plata, que era la única disponible, se perdería el norte de Italia y el «camino español». ${ }^{21}$

${ }^{18}$ Chamorro 1998; Elliott 1990. «Hay una relación indudable entre la mediocridad de las remesas de plata y la laxitud de la política exterior española en 1626-28». En 1625 solo llegó la flota de Nueva Espańa y la de Tierra Firme tuvo que hacer invernada, llegó en 1626 con 1,492,977 que parecía ser bastante pero por diversas cuestiones se gastó muy rápido. En 1627 llegaron aun menos, 1,500,000 pesos entre ambas flotas, y Felipe IV se declaró en quiebra por primera vez. Por último, en 1628 fue el robo de la flota de Nueva España y no llegó la de Tierra Firme hasta 1629 (Domínguez Ortiz 1998: 64-65). ${ }^{19}$ Calderón 2005: 540, 556-557; Díaz Blanco 2012: 126.

${ }^{20}$ Además, Felipe IV amagó con irse personalmente al frente de batalla como había hecho su homólogo francés. A este respecto se convocó la Junta Grande para revisar algunos arbitrios que se habían recibido de Pedro de Vivanco, consejero de Indias. Estos prometían un medio adecuado de extraer recursos de los virreinatos americanos sin dañar a los súbditos. Sin embargo, los arbitrios parecieron ser muy radicales y el Consejo refutó la mayoría. De tal manera, se aprecia cómo el sínodo, en ocasiones, prefería respetar a las instituciones americanas para compensar los intereses de las élites locales con los del poder central, aun cuando estos podían significar grandes ganancias para la Real Hacienda. Para este caso, véase Amadori 2008: 67; 2011: 282-293.

${ }^{21}$ Amadori 2011: 286-292; Díaz Blanco 2012: 126-127; Domínguez Ortiz 1998: 67-69. 
Consecuentemente, «si en 1628 Piet Heyn había hecho desaparecer el dinero de los cargadores, en 1629 lo había conseguido Felipe IV, que se lo reintegraría (o intentaría hacerlo) en juros sobre los millones de varias ciudades españolas». ${ }^{22}$ Esto fue una especie de títulos de deuda perpetua al $6.3 \%$, además de que se concedieron hábitos a varios mercaderes, incluidos los peruanos. A simple vista parecía ser una indemnización aceptable, si no se tomara en cuenta la inseguridad de la paga, la depreciación del vellón y que los mercaderes necesitaban capitales líquidos para mantener sus negocios, no rentas vitalicias. ${ }^{23}$ Por si fuera poco, el Cabildo de Sevilla había aceptado ayudar a la Corona con 500 mil ducados y para ello había subido un $0.25 \%$ en concepto de almojarifazgos, medida que afectaba directamente a los mercaderes y que se había tomado sin consultarles. ${ }^{24}$

Aun así, la situación bélica era insostenible y Olivares había vuelto a buscar apoyo por parte del emperador. Este acudió, pero prefirió combatir a los franceses en Italia que a los holandeses. Ello evitó que los Habsburgo invadieran las Provincias Unidas conjuntamente. De tal suerte, Segismundo III de Polonia, al no recibir el apoyo que esperaba por parte de los Habsburgo en el Báltico, se vio forzado a firmar la Tregua de Altmark con Gustavo Adolfo de Suecia. Esa conjunción de sucesos finiquitó toda posibilidad de destruir el comercio holandés por el Báltico, además de que las tropas imperiales depositadas en Mantua restablecieron el equilibrio, pero no aseguraron una victoria, pues el emperador se vio más preocupado por proclamar el Edicto de Restitución en sus territorios. ${ }^{25}$

Entonces Felipe IV esperaba recibir ayuda extra de las Indias pero, al otro lado del Atlántico, en México, se sufrían igualmente, o peor, las consecuencias de la flota perdida. El comercio novohispano había sido profundamente herido ${ }^{26}$ y ello había provocado un efecto dominó

${ }^{22}$ Díaz Blanco 2012: 127. El embargo se haría en Cartagena (Domínguez Ortiz 1998: 69).

${ }^{23}$ Domínguez Ortiz 1998: 69; Suárez 2015: 129.

${ }^{24}$ Díaz Blanco 2012: 127.

${ }^{25}$ Bonney 2002: 190; Chamorro 1998: 190; Elliott 1990: 160; Parker 2003: 140-141.

${ }^{26}$ Desde este año el virrey comenzó a aceptar a manifestación mercancías que llegaban en la nao de China, excusándose con la situación en que se encontraba el comercio. Carta del virrey marqués de Cerralbo al rey, México, 21 de enero de 1629, AGI, México, 30, 
al imposibilitar la inversión necesaria para la operación de las minas, con lo cual la economía se estaba derrumbando. ${ }^{27} \mathrm{El}$ virrey, presionado por complacer al rey y asegurarle ingresos fiscales, al tiempo que tenía que garantizar la defensa del virreinato y destinar sumas importantes de dinero para las plazas del Caribe y Filipinas, que cada vez tenían que ser más cuantiosas conforme la guerra se había vuelto global; dejó a un lado las obras del desagüe de la ciudad de México, a pesar de la insistencia del Ayuntamiento, temeroso de aprobar una obra tan costosa que no fuera aprobada por el monarca en tiempos de tanta necesidad. Por desgracia, en septiembre cayeron descomunales lluvias que inundaron la ciudad al grado que se pensó que se iba a perder por completo, miles de indios perecieron y muchas familias españolas y criollas emigraron a otras ciudades. ${ }^{28} \mathrm{Si}$ el robo de la flota había varado la economía novohispana, ahora la naturaleza la había hundido por completo.

Existía una dependencia mutua entre el estado de la corporación mercantil y su poderío económico local, con el funcionamiento de la administración y el aumento de las remesas para la Península. ${ }^{29} \mathrm{Al}$ ser el centro administrativo y económico del virreinato, si México sufría una catástrofe, esta no solo tenía efectos a nivel local, sino en toda la monarquía. Es curioso que, antes de recibir la terrible noticia, los consejeros,

n. 12, f. 2. Admitir «a manifestación» plata o mercancías era una de las posibles respuestas al contrabando, legalizando su paso mediante el cobro de derechos. Esta práctica llegó a ser relativamente frecuente y de esa manera se conseguía que la Corona recibiera una bonificación y los comerciantes podían vender sus mercancías a precios razonables sin alterar el mercado con tanto producto tan barato que no había pagado derechos. No obstante, en 1626 había sido terminantemente prohibido por la Corona (Rodríguez Vicente 1960: 278).

${ }^{27}$ Calderón 2005: 540, 556-557.

${ }^{28}$ Calderón 2005: 486-487; Riva Palacio 1981: 129; Rubio 2005: 47-51. Estudios climatológicos recientes han demostrado que, durante el periodo en que fue rey Felipe IV, hubo en todo el mundo fenómenos naturales anormales: sequías, lluvias torrenciales o inviernos extraordinariamente fríos que generaron migraciones, epidemias y hambrunas. Ello generó una serie de crisis sociales alrededor del mundo, que si bien no fue la primera que experimentó la humanidad, si fue la primera en dejar abundantes testimonios escritos alrededor del globo (Parker 2006).

${ }^{29}$ Amadori 2011: 307. 
conscientes del daño que estaba sufriendo el comercio trasatlántico y de las dificultades por las que pasaban las Indias, escribían al rey: «Siente mucho este Consejo que las cosas de Indias hayan descaecido de aquel estado y prosperidad antiguas». ${ }^{30}$

Cinco días después de escritas esas palabras, y probablemente también sin saber la noticia de la inundación, en Perú se despachaba un auto para enviar un navío de permiso a la Nueva España para que se hiciera a la vela el siguiente mes y, "aunque el permiso no es más de 200,000 duros de Castilla, por cosa muy sabida, hay 70 cargadores contados que pretenden ir a emplear a México». ${ }^{31}$ Grandes comerciantes limeños invirtieron su dinero, sobre todo el banquero Juan de la Cueva, dueño del navío cuyo nombre era San Francisco; y hasta el virrey Chinchón estuvo envuelto. Para "prevenir no lleve más plata que la cantidad del permiso, se ha mandado que no se de licencia a navío ni barco grande ni chico para salir del puerto hasta que haya hecho a la vela este, pero sin embargo, la común opinión es que llevará más de un millón». ${ }^{32}$ Cueva había enviado el año anterior un navío llamado San Juan Evangelista, y esperaba que las ganancias del San Francisco, volvieran a la brevedad en aquél. ${ }^{33}$ Pero aquello terminaría muy mal para los inversores, como se verá más adelante. ${ }^{34}$

${ }^{30}$ Consulta del Consejo de Indias, Madrid, 10 de noviembre de 1629, AGI, Indiferente, 2690, f. 87. Al ver que las aguas habían llegado para quedarse, el Cabildo de México escribió a Felipe IV explicando que el virreinato se encontraba en una situación crítica, con lo cual quedaba totalmente incapacitado para contribuir a la Unión de Armas. (Carta del Cabildo de México, México, 17 de diciembre de 1629, AGI, México, 318).

${ }^{31}$ Suardo 1935: 29.

${ }^{32} \mathrm{Ib}$.

${ }^{33}$ Suárez 2015. El San Francisco llegaría a Acapulco en 1630. Felipe de Mieses y Esteban Castellanos decidirían no retornar el mismo año a Perú pues solicitaban llevar sus mercancías en la fragata Nuestra Señora del Rosario, a lo mucho para mayo del siguiente (Sales Colin 2000: 113). Ante la demora en su regreso, en Lima se suspendería el envío del navío correspondiente a ese año de 1630 por común acuerdo en el Consulado y se plantearía que en el futuro no se enviara anualmente sino cada dos (Rodríguez Vicente 1960: 246).

${ }^{34}$ El envío de 1629 tendría consecuencias fatídicas pero estas no se harían sentir con todo rigor hasta 1633. De hecho, sería un factor importantísimo para la prohibición en 1634. 


\section{EL PESO DEL IMPERIO (I 630-I63 I)}

Así como Chinchón estaba involucrado en negocios sospechosos por la Mar del Sur, era sabido que su homólogo en Nueva España lo estaba más. ${ }^{35}$ Para esos momentos ya se estaban llevando a cabo investigaciones sobre fraudes en el puerto de Acapulco pero, extrańamente, en enero de 1630, se ordenó la suspensión de las pesquisas hasta que llegara el momento de efectuar la residencia del virrey. ${ }^{36}$ Ello revela que la Corona era plenamente consciente de que Cerralbo estaba involucrado en el contrabando por el Pacífico, pero probablemente tomó aquella medida para no dañar la reputación de la autoridad virreinal ante el pueblo, y por ende de la monarquía. ${ }^{37}$

El año de 1630 solo fue a demostrar que las cosas no mejorarían para Felipe IV y su monarquía. La Compañía Holandesa de las Indias Occidentales efectuó su mayor conquista territorial al tomar Caracas, Olinda, Recife y Pernambuco, además de la isla caribeña de San Martín. Todo ello ponía en mayor riesgo el tráfico trasatlántico español. ${ }^{38}$ El frente de Italia seguía atascado y absorbiendo recursos, mientras que había sacado a relucir las diferentes prioridades entre los Habsburgo ibéricos y los austriacos. ${ }^{39}$ De tal suerte, el rey de Suecia, que se había sentido amenazado por los frustrados proyectos que los católicos habían proyectado en el Báltico, halló el momento preciso para dar un golpe de autoridad invadiendo Alemania, la cual penetró avasallantemente y a una velocidad asombrosa. ${ }^{40}$

${ }^{35}$ Cuando había estado el visitador Martín Carrillo lo había denunciado al menos desde 1627 (Israel 1980: 177). De hecho, se decía que Cristóbal Bonilla Bastida le ocultaba las mercancías. Por otro lado, don Antonio Urrutia de Vergara, nombrado maestre de campo, era una especie de valido del virrey y actuaba también como su agente comercial. Este había llegado con mercancías consignadas y se había casado con la hija de un mercader, además de que se le veía mercadeando en público (Schell 1991: 156, 178).

${ }^{36}$ Consulta del Consejo de Indias, Madrid, 19 de enero de 1630, AGI, México, 3, n. $128 \mathrm{a}$.

${ }^{37}$ Esta se encontraba en una posición muy delicada desde el levantamiento de 1624 en contra del virrey Gelves (Cañeque 2004: 243).

${ }^{38}$ Amadori 2011: 361; Israel 1990: 33, 280; Wilson 2009: 658.

${ }^{39}$ Parker 2003: 141.

${ }^{40}$ Bonney 2002: 9; Chamorro 1998: 110. 
Algo reconfortante fue que, en agosto, llegó a Sevilla Fadrique de Toledo resguardando ambas flotas de Indias con uno de los mayores tesoros que se habían visto. Pero pronto fue evidente que ni siquiera ello sería suficiente para costear los gastos de la monarquía, además de que la invernada que había tenido que hacer en América había sido demasiado costosa. Los agentes reales entonces calcularon un pago de entre 500 mil y un millón de ducados por parte de los comerciantes sevillanos. Naturalmente, estos protestaron, sosteniendo que el aumento de $5 \%$ que habían hecho en la avería debería haber costeado la invernada. Además, el rey solicitó también un préstamo forzoso para financiar el frente de Italia. Ante las extorsiones, y a sabiendas de que, si no cumplían los deseos del rey, este simplemente podía ordenar a los funcionarios de la Casa de la Contratación que embargasen la plata, los comerciantes terminaron entregando 600 mil ducados por la invernada y 500 mil a préstamo. ${ }^{41}$ Solo entonces Felipe IV escribió «Dense muchas gracias al comercio y véase en qué se le puede hacer merced». ${ }^{42}$ A pesar de todo ello y de que la gente de Castilla sufría hambre, Felipe IV y su valido dieron inicio a la construcción del Palacio del Buen Retiro, obra costosísima y vista con consternación por muchos, que sería sufragada principalmente con plata peruana. ${ }^{43}$

Mientras tanto, durante la transición entre 1630 y 1631, en México se seguía sufriendo la inundación. El impuesto que se había establecido para costear las obras del desagüe fue de 25 pesos por cada pipa de vino desembarcada en Veracruz. ${ }^{44}$ Con todo, a principios de 1631, el virrey intentaba que entrara en vigor la Unión de Armas, para la cual se había establecido un aumento de la alcabala del 2 al $4 \%$, y el cobro de un real por cada baraja de naipes. Con estas medidas se buscaba perjudicar al

${ }^{41}$ Díaz Blanco 2012: 129-131; Domínguez Ortiz 1998: 70-71.

${ }^{42}$ Consulta del Consejo de Indias, Madrid, 27 de septiembre de 1630, AGI, Indiferente, 756.

${ }^{43}$ Amadori 2011: 239; Brown y Elliott 1988; Chamorro 1998.

${ }^{44}$ Carta del virrey marqués de Cerralbo al rey, México, 24 de enero de 1630, AGI, México, 30, n. 27, f. 11. Ello lógicamente disgustó a los cargadores de Sevilla, quienes no sentían obligación de pagar por un problema que no les competía (Consulta del Consejo de Indias, Madrid, 17 de mayo de 1630, AGI, México, 3, n. 123). 
menor número de personas pero se afectaba nuevamente al comercio. ${ }^{45}$ El Consulado se opuso recordando que, con la pérdida de la flota y la inundación, la ciudad había quedado en menos de la tercera parte de su anterior opulencia y, ante la escasez, habían subido los precios. Los ingresos de la cuartilla de vino eran insuficientes para sobrellevar las obras de desagüe, por lo que algunos comerciantes habían tenido que conceder donativos. A ello se sumaba, entre otras cosas, el retraso en la Nao de China. Con todo, lograron aplazar su aplicación un año más. ${ }^{46}$

Además, las minas de azogue de Huancavelica habían comenzado a presentar bajas en su producción. Con la escasez de un producto fundamental para su funcionamiento se contribuyó a la contracción de la minería americana. ${ }^{47}$ Por ello, en Nueva España volvió el ya viejo debate sobre importar ese preciado elemento de China y el Consejo terminó dando el visto bueno frente a la necesidad de remesas. ${ }^{48}$

En Madrid el rey había encomendado al Consejo que eligiera dos agentes, uno para la Nueva España y otro para el Perú, para que viajaran con la misión de implantar arbitrios que aumentaran los ingresos de la Corona. Para el Perú se designó a Hernando de Valencia, pero para el virreinato septentrional los consejeros consideraron que era mejor excusarse, pues

después de haberse pedido dos donativos desde que Vuestra Magesatad entró en estos reinos, y perdido una flota y tantas naos de Honduras, se ha acabado de asentar la imposición de [...] la Unión de Armas de Vuestra Magestad ${ }^{49}$, y consistiendo el comercio el nervio principal de aquel reino, en los vecinos de México se deja considerar la aflicción que estarán viéndose con tantas

\footnotetext{
45 Schell 1991: 198-199.

${ }^{46}$ Véase Casado Arboniés 1986: 126-127.

${ }^{47}$ Amadori 2011: 255; Calderón 2005: 540, 556-557; Israel 1990.

${ }^{48}$ Consulta del Consejo de Indias, Madrid, 25 de septiembre de 1630, AGI, Indiferente General, 1777. Desde aquí ya se busca con Antonio Balbi y se considera lo de China para el futuro, a lo que se accede en 1631. Véase también Copia de carta de los regidores al virrey en carta del virrey marqués de Cerralbo al rey, México, 21 de agosto de 1631, AGI, México, 30, n. 36, ff. 42-47, y Valdés Lakowsky 1987: 61.

${ }^{49}$ Esa era una idea errónea del Consejo probablemente derivada de la correspondencia de Cerralbo pues, como se ha visto, los regidores habían logrado retrasar la imposición.
} 
calamidades e inundación de aquella ciudad que todavía está padeciendo con grandes pérdidas de hacienda que puede dudar de su recuperación. ${ }^{50}$

De tal manera, la crisis novohispana repercutió en el Perú pues, aunque en aquel virreinato tampoco había sido implantada todavía la Unión de Armas, se convertiría en el centro donde llevar a cabo una serie de arbitrios fiscales. Consternado por la presión, el virrey Chinchón llegaría a afirmar que «la gente de acá [está] más crespa e inquieta que la de Nueva España». ${ }^{51}$

$\mathrm{Y}$ es que, para este punto, los americanos ya se preguntaban cuál era realmente su papel dentro de la monarquía, pues ser leales al rey no implicaba poseer un común de intereses con el resto de los reinos, especialmente porque las élites indianas estaban conscientes de que mucho de su dinero terminaba siendo gastado en empresas militares tan lejanas como el norte de Europa, ${ }^{52}$ al tiempo que se limitaban sus medios de producción y sus empresas comerciales y se llegaba al grado de tomar por la fuerza la plata que les pertenecía. De hecho, después de las incautaciones del año anterior, el comercio había quedado destruido y sin capacidad alguna de contribución durante este año de $1631 .{ }^{53}$ Buscando templar los ánimos y evitar más conflictos, por cédula de 14 de mayo, Felipe IV prometió no volver a tomar dinero de manera forzosa a los mercaderes. ${ }^{54}$

${ }^{50}$ Consulta del Consejo de Indias, Madrid, 28 de marzo de 1631, AGI, Indiferente, 2690 .

51 Israel 1990: 275.

52 Según fray Buenaventura de Córdova y Salinas, «Flandes cuesta a Su Magestad más de doscientos y ochenta y cuatro millones de oro y plata y más de trescientos cincuenta mil hombres; y yo digo, y todos lo dirán, que la parte no puede recompensar lo gastado, cuánto más lo que va gastado. Pues mucho será que habiendo dado el Perú su sangre y su sustancia, fundida en tantos millones a sus reyes, lo menosprecien y se olviden de él cuando lo apuran y combaten enemigos y entrando todos por su estrecho nunca los siga en su favor España, y siempre le aten las manos a un virrey, para que no gaste en beneficio suyo» Córdoba, 1631: 255 (Cit. en Amadori 2011: 304-305).

${ }^{53}$ Díaz Blanco 2012: 132.

${ }^{54}$ Domínguez Ortiz 1998: 72. 
Ese mismo mes, el Consulado de Lima presentó un memorial respecto del comercio con la Nueva España. Hasta el momento no se habían recibido las ganancias del navío enviado en 1629, razón por la cual se había decidido no enviar en $1630 .{ }^{55}$ Había ascendido a prior del Tribunal Juan de Urrutia, quien solía traficar la ruta hacia Acapulco y era uno de los agentes contratados por los comerciantes mexicanos más importantes. Aun defendía la idea de que convenía más cerrar por completo dicho comercio a continuarlo bajo las regulaciones vigentes, por ello proponía que se continuase el navío con permiso de $200 \mathrm{mil}$ ducados pero con la posibilidad de adquirir géneros orientales, pues su censura acarreaba muchos daños.

Primero, el Consulado limeño sostenía que, estando la ciudad de México inundada y el tráfico de mercancías limitado a géneros de la tierra, los limeños que habían realizado el viaje en 1629 no hallaban mercancías ni mercaderes, por lo que llevaban ya ańo y medio buscando qué comprar, mientras que, en las épocas en las que habían tenido permiso de adquirir productos chinos, sus viajes no solían durar más de diez meses. En segundo lugar, esgrimía que la medida no era justa, pues solo se prohibía a los peruanos la adquisición y uso de textiles asiáticos, donde por la naturaleza del clima eran muy necesarios, mientras que en las islas de Barlovento y en la Península misma sí podían gozar de ellos. En tercer lugar, desde la prohibición, dichas mercancías habían subido considerablemente de precio afectando a los más necesitados de Lima y las que entraban de contrabando, causaban desórdenes en el mercado y afectaban tanto a limeños como a peninsulares. El cuarto punto señalaba que los mercaderes eran hostigados por los oficiales reales, quienes buscaban las mercancías prohibidas como si se tratara de enemigos a los que había que saquear. Por ello, algunos se esforzaban en desembarcar en lugares solitarios y terminaban siendo asaltados por bandidos. El quinto trataba el tema de la demanda americana de productos castellanos, los

${ }^{55}$ Aunque ello también se había debido a que la minería peruana aún no se recuperaba por completo de la guerra de vicuńas contra vascongados (1622-25) y por la crisis de falta de azogue, además de que en 1629 el rey incautó las remesas de los peruanos que llegaron a Sevilla (Suárez 2015: 129). 
cuales, si el Perú adquiriera menos, bajarían de precio en beneficio de los vasallos peninsulares que los necesitaban. Además, solamente solicitaban un permiso de 200 mil ducados de géneros orientales, mientras que cada año se enviaban a España entre cuatro y cinco millones. Por último, remarcaban el hecho de que, al ser permitidas, el rey se beneficiaría de los impuestos que pagarían, mientras que, como se encontraba hasta entonces, no se le sacaba provecho ni a las decomisadas, que debían ser enviadas a España donde supuestamente habían de ser incineradas. ${ }^{56}$

Es destacable que el Consulado no mencionó en estos memoriales a los funcionarios reales como algunos de los actores más problemáticos de ese comercio. Probablemente, prefirió ser cauteloso, consciente de que las autoridades virreinales eran las que podían paliar o aumentar la presión fiscal que solicitaba Madrid. No obstante, no hay dudas de que los oficiales reales, gobernadores y virreyes hacían de las suyas en esos tratos. ${ }^{57}$

Fue hasta agosto de 1631 que llegó a Lima la noticia de que, en febrero, habían arribado las naos de China a Acapulco cargadas de mercancías riquísimas. Asimismo, se supo que los navíos peruanos, San Juan Evangelista y San Francisco, enviados en 1628 y 1629, respectivamente, habían sido comprados por el rey para ser despachados a Filipinas, pero que no faltarían embarcaciones en las que pudieran volver los agentes que habían viajado en ellos a Nueva España. ${ }^{58}$ Esa información no era del todo puntual, pues no habían sido comprados sino embargados. ${ }^{59}$ Probablemente, el virrey de Nueva España, ante la falta de naos, se vio obligado a hacerlo para reactivar la economía y combatir la crisis por la que atravesaba su virreinato, sabiendo perfectamente que, si había

${ }^{56}$ Rodríguez Vicente 1960: 251-252; Suárez 2015: 127.

${ }^{57}$ En Perú era frecuente que los virreyes ofreciesen enviar navíos de permiso a México a cambio de que los comerciantes les prestaran plata para engrosar las remesas a la Real Hacienda. También era común que los oficiales reales en Acapulco forzaran a fletar o incluso vender los navíos peruanos a la Real Hacienda novohispana para ser embarcados hacia Filipinas — tal y como había ocurrido con los de 1629—, a cambio de darles permiso para comerciar directamente en el archipiélago (Suárez 2015: 127-128).

58 Suardo 1935: 145.

${ }^{59}$ Suárez 2015: 117-120. 
algo que podía darle empuje, era justamente el comercio con Filipinas. No obstante, ese suceso tendría consecuencias muy importantes que se harían sentir más adelante. ${ }^{60}$

Dejando ese detalle a un lado por el momento, es muy sugestiva la carta que envía Cerralbo al rey sobre las dichas arribadas, donde se alegra de lo mucho que habían sumado los derechos que se habían cobrado, debiéndose a «haber querido Dios traer en salvamento este año dos naos [de Filipinas] tan ricas en tiempo que México estaba muy lleno de dinero, así sus vecinos como los del Perú» ${ }^{61}$. Parece olvidarse por completo de las leyes vigentes y confesarle al rey abiertamente que los agentes peruanos comprarían mercancías asiáticas con singular alegría. También el diario de Juan Antonio Suardo, clérigo avecindado en Lima, recoge el interés que mostraron los peruanos en las mercancías asiáticas que habían llegado a Acapulco. A través de su relato se puede deducir la complicidad de ambos virreyes en el contrabando pues, contra toda ley, se dice que Cerralbo envió una fragata de Acapulco a Piura con más de 400 mil pesos en mercancías. Luego, Chinchón se puso a organizar el envío, no de uno, sino de dos navíos de permiso del Callao a Acapulco, que serían enviados a fin de año. ${ }^{62}$ Un documento de diciembre de 1631 informa que, una vez que los oficiales reales finalizaban la inspección de los navíos, las autoridades del Callao disparaban una salva para detenerlo con el pretexto de enviar un mensaje especial al virreinato de la Nueva España, aprovechando esa puesta en escena para cargar más plata ilegal, ${ }^{63}$

${ }^{60}$ Las consecuencias no se harían sentir con todo rigor hasta 1633 y serían un factor importante para el cierre del comercio entre ambos virreinatos.

${ }^{61}$ Carta del virrey marqués de Cerralbo, México, 21 de agosto de 1631, AGI, México, 30, n. 36. Esta declaración no solo muestra ilegalidad, sino que además contradice la crisis en la que tanto había insistido en que se encontraba el comercio de Nueva España. Aún más desconcertante resulta al contrastarla con otra carta que escribió menos de un mes después: «El comercio ha sentido tiernamente lo que se le cargó en Sevilla por los gastos de la armada real, y con esto y los recelos de enemigos en la mar, están muy desanimados los cargadores, procuro alentarlos lo posible» (Carta del virrey marqués de Cerralbo, México, 9 de septiembre de 1631, AGI, México, 30, n. 39).

${ }^{62}$ Suardo 1935: 154. 156, 158, 162.

${ }^{63}$ Por ello, Felipe IV, más tarde prohibiría tajantemente que cualquier navío se detuviera una vez que se hubiera hecho a vela, a menos que fuera por orden expresa del virrey 
plata que terminaría en manos chinas. ${ }^{64}$ Baste decir que, en otra carta de Cerralbo a Felipe IV sobre llevar azogue de China al Perú, quedaba en ponerse de acuerdo, tanto con Chinchón, como con el gobernador de las Filipinas para llevar a buen puerto la transacción, y finalizaba diciendo «si bien habrá de salir de los reinos de Vuestra Magestad buena cantidad de plata, en ninguna parte será de menos daño que en la China». ${ }^{65}$

Pero plata era lo que necesitaba la Corona más que nunca pues, con la intervención sueca, la causa católica se encontraba al borde del desastre. El emperador había tenido que retirar a sus fuerzas del norte de Italia para llevarlas a Alemania y, consecuentemente, los Habsburgo se habían visto obligados a firmar la Paz de Cherasco, poniéndole fin a la guerra de Mantua en julio de 1631, con condiciones ventajosas para los franceses. Olivares había invertido todos los ingresos indianos a la Real Hacienda y buena parte de lo arrebatado a los particulares en ese rotundo fracaso ${ }^{66}$ y mantener tres frentes de batalla había llevado a aumentar las gravosas demandas tributarias que tenían sumamente presionados a los súbditos castellanos. ${ }^{67}$ Quizá con cierta presciencia, el conde duque, desilusionado con los virreinatos americanos por no cumplir las expectativas, escribió: «Las grandes conquistas [...] han puesto esta monarquía a tan miserable estado, que se puede decir, con gran fundamento, que fuera más poderosa si hubiera menos aquel Nuevo Mundo». ${ }^{68}$ Solo dos días después de plasmadas esas palabras, Cerralbo escribía orgullosamente que enviaba en la flota la prometedora cantidad de $1,447,858$ pesos para la Real Hacienda, y declaraba que los derechos de Filipinas habían montado más que ningún otro año, alcanzando la cantidad de 252,400

(Rodríguez 1960: 271). Sin embargo, no hay razones para dudar que la orden proviniera precisamente del virrey.

${ }^{64}$ Precisamente en 1631, en Japón se prohibió por completo la exportación de plata hacia el exterior. Este era la segunda fuente de plata para China, por lo que ahora aumentaría su demanda de la americana (Valdés 1987: 106).

${ }^{65}$ Carta del virrey marqués de Cerralbo, México, 14 de agosto de 1631, AGI, México, 31, n. 1 .

${ }^{66}$ Bonney 2002: 9; Chamorro 1998: 110; Lynch 2007: 500; Parker 2003: 141-142.

${ }^{67}$ Chamorro 1998: 191; Elliott 1990: 162.

${ }^{68}$ Elliott 1990, p. 48. 
pesos, tratando de probar que sus medidas habían surtido efecto y que el virreinato salía adelante contra las calamidades. ${ }^{69}$ Pero más infortunios aguardaban a la monarquía, en octubre, la flota fue desmembrada por un ciclón que hundió a la mayoría de las embarcaciones, perdiéndose alrededor de cinco millones de ducados entre tesoro real y de particulares. La funesta noticia tocó Madrid hasta marzo de 1632 y Olivares expresó que la aflicción que sentía no podía explicarse con palabras. ${ }^{70}$

\section{LA PRESIÓN CONTINÚA (I632)}

En cierta manera, muchos ministros castellanos ya percibían el imperio más como una carga que como un beneficio, y es que las Indias podían ofrecer tesoros de ensueño, pero también acarreaban un sinfín de problemas. De hecho, últimamente parecían brindar solo los segundos, pues las riquezas ya no llegaban a Castilla sino que se quedaban en América o fluían directamente a Asia, y cuando llegaban, se iban de sus manos como agua: los galeones de Tierra Firme habían invernado en La Habana y arribaron a la Península en abril, acompańados por las dos únicas naos de Nueva España que se habían salvado. Las remesas para la Real Hacienda habrían montado un millón de pesos de no ser porque se le tuvo que restar lo que se había entregado a los presidios del Caribe, además de lo de avería, invernada y lo correspondiente a la Casa de la Contratación. Al rey casi no le quedó nada con que pagar a los asentistas y a Olivares le pegó tan duro que escribió al presidente de la Casa de la Contratación: «me parece que se puede tener por cierto [...] que esta monarquía cae de golpe y que Su Magestad tiene aventurada su corona». ${ }^{71}$

Ello porque los suecos ya tenían bajo su poder casi toda Alemania y la situación en Flandes parecía al borde del colapso, además de que, en el Caribe, los holandeses habían tomado Tobago. Consecuentemente, hubo que apretar aun más los impuestos dentro de Castilla. ${ }^{72}$ No obstante,

${ }^{69}$ Carta del virrey marqués de Cerralbo, México, 9 de septiembre de 1631, AGI, México, leg. 30, n. 39. (Véanse también n. 40-41.)

${ }^{70}$ Calderón 2005: 524; Domínguez Ortiz 1998: 73, 180; Lynch 2007: 501, 608.

${ }^{71}$ Domínguez Ortiz 1998: 74.

${ }^{72}$ Israel 1990: 34; Lynch 2007: 503, 512. 
no todo lo que llegó del Nuevo Mundo fueron malas noticias, también se supo que en Nueva España había quedado por fin asentada la Unión de Armas y, desde principios de año, se estaba cobrando el aumento en las alcabalas. ${ }^{73}$ Con ello se lograría recaudar el doble de los años previos, llegando a 180 mil pesos anuales en la ciudad de México, mientras que se recibirían 50 mil por parte de Puebla y 22,500 de Veracruz, entre otras. ${ }^{74}$

Pero esos ingresos tardarían todavía varios meses en llegar y la situación no daba para esperar. Una vez más, el rey y sus ministros voltearon su mirada hacia los cargadores de Sevilla. El debate duró de mayo a julio de 1632, pues se esperaba que abonaran en efectivo una parte de los 600 mil ducados que se calculaba valdrían el crecimiento de los juros, por ello se pedían al menos 200 mil para satisfacer las consignaciones de los negociantes que asistían a los frentes de Flandes, Alemania e Italia, así como a las armadas. Desafiante, el Consulado exigió a cambio que se le pagasen varios de los préstamos que había hecho desde 1629, pero el rey ordenó que se tomara la plata por la fuerza, además de que también se le sumaron 30 mil ducados de un asiento y se aumentó 1\% de impuesto sobre las mercancías que serían enviadas a Indias durante los próximos seis años para financiar un cuerpo de 500 infantes. Casi de inmediato, en agosto, tuvieron que aceptar un acrecentamiento en la avería del 6 al $10 \%$ para que la Real Hacienda tomara 174 mil ducados de los fondos acumulados por dicho impuesto, aun cuando en el Consejo se oponía Juan de Solórzano Pereyra, sosteniendo que se destruiría el comercio. ${ }^{75}$

Ese comercio del que tanto dependía España se encontraba en una marcada decadencia pero, como siempre, hubo personas que levantaron la voz, pues creían saber cuál era el problema y su posible solución. ${ }^{76}$

${ }^{73}$ Carta del virrey marqués de Cerralbo, México, 18 de diciembre de 1632, AGI, México, 31, n. 29. En Perú quedaría asentada hasta 1639. Al respecto, véase Amadori 2011 y Bronner 1975.

${ }^{74}$ Valle Pavón 2003: 48; Schell 1991: 22, 191-192.

${ }^{75}$ Díaz Blanco 2012: 132-137.

${ }^{76}$ En opinión de los ministros de la Casa de la Contratación y del Consulado de Sevilla, el comercio trasatlántico estaba siendo erosionado por 4 factores principalmente: primero, había contrabando y corrupción en el embarco de bienes dentro de la propia Carrera de Indias. En segundo lugar, desde la década de 1580, los judeoconversos portugueses 
Tal es el caso del arbitrista Francisco de Vitoria Barahona que, estando en la corte, había entregado un memorial en marzo de 1632 donde exhibía su amplia experiencia en Indias. ${ }^{77}$ Respecto del comercio triangular del Pacífico, no era muy innovadora su postura en relación a las que otros habían escrito, pero la dotaba de un espíritu mucho más estadista. En vista de que parecía imposible coartar el contrabando, pensaba que lo mejor que se podía hacer era sacarle provecho. Es decir, legalizar el ingreso de las mercancías en la cantidad y géneros que ya lo hacían ilegalmente, pero con una extraordinaria mejora en el registro para garantizar que se cobrasen tajantemente los derechos debidos. Proponía que, para la arribada de las naos, se contase con la presencia de un oidor y un fiscal real, los cuales no fuesen siempre los mismos, sino que fuesen rotando cada año. De igual manera se debía colocar vigilancia especializada en Realejo y en San Juan de Ulúa para que no se llevase mercadería china a Tierra Firme sin pagar. Según sus cálculos, de Filipinas se enviaban a Nueva España anualmente entre seis y ocho millones de pesos en mercancías, que si se les cobrase el 15\%, montarían 900 mil pesos; del Perú salían hacia Nueva España entre tres y cuatro millones de pesos que, al cobrarse $5 \%$ a la salida, sumarían 150 mil pesos, y al regreso, $15 \%$, equivalente a 450 mil pesos. Sumado todo lo anterior, si la Corona aprovechaba ese comercio, podría ganar para su Real Hacienda más de

habían estado contrabandeando plata no registrada desde Potosí hasta Brasil a través del Río de la Plata, pasando por Buenos Aires. En tercero, había otro contrabando portugués por medio del navío de permiso que llevaba esclavos africanos directamente a las Indias españolas, donde, naturalmente, también se embarcaban otro tipo de mercancías. Y, sobre todo, la pérdida de plata americana vía la nao de China a cambio de sedas y otros productos que competían con los peninsulares (Israel 1990: 274).

${ }^{77}$ El capitán Francisco de Vitoria estuvo veinte años «gastando mucho tiempo y gran parte de su hacienda, dejando sus contrataciones, recorriendo las Indias por mar y tierra, calando los comercios y provincias y contrataciones y conversando con diversidad de gentes». A través de esas experiencias se dio cuenta de la mala administración que tenía la Real Hacienda y en particular en el fraude que se hacía con respecto del quinto real. Decidido en servir, dejó a su familia en Perú y viajó a la corte alrededor de 1629 para ofrecer a Felipe IV una manera de beneficiar su Real Hacienda. Relación de méritos y servicios de Francisco Vitoria Barahona, Madrid, AGI, Escribanía, 1024b; Consulta del Consejo de Indias, Madrid, 24 de agosto de 1634, AGI, Indiferente, 758. 
1,500,000 anualmente. Además, explicaba que no existían mercancías en el mundo a las que se les hiciera mayor empleo respecto de su valor inicial, pues si a las peninsulares se les ganaba entre el 7 y el 20\%, a las chinas más del 100\%. Concluía que la única otra alternativa era cortar de tajo el comercio entre Nueva España y Perú. ${ }^{78}$

El memorial de Vitoria fue remitido a la Real Junta de Minas a la que se agregó a Juan de Solórzano Pereira y Francisco de Alfaro, ambos que habían sido oidores en la Audiencia de Lima; don Martín Carrillo, visitador que había sido de Nueva España — ahora obispo de Oviedo-; y don Luis Fernández de Córdoba, señor del Carpio, que había sido general de la Carrera de Filipinas. La Junta fue muy crítica cuestionando las propuestas, por lo que las determinaciones tardarían mucho todavía. ${ }^{79}$

Paralelamente, en Perú, el contador Hernando de Valencia, que había sido enviado a garantizar la implantación de ciertos arbitrios, en su informe de junio de 1632 denunciaba los conocidos dańos que generaba el comercio con México: fraude, contrabando, excesos, desórdenes financieros, saturación del mercado para los que buscaban vender mercancías europeas, etcétera. Por lo cual, llegaba a conclusiones similares a las de Vitoria, estableciendo que ese trato se tenía que liberalizar del todo o cerrarse por completo. ${ }^{80}$

Por su parte, en Nueva España se observaban todos los elementos que hacían que el comercio trasatlántico estuviera en decadencia. El aumento en la alcabala para la Unión de Armas y en la avería incitaba a los inconformes mercaderes a recurrir al contrabando y el fraude. ${ }^{81} \mathrm{Al}$ mismo tiempo, el virreinato tenía que sostener los situados y los gastos de defensa, con lo cual, los fondos que se invertían en construcción de fortificaciones, provisión de armadas y sustento de las guarniciones se quedaban en las Indias y dinamizaban la economía virreinal, pero

${ }^{78}$ Memorial de Francisco de Vitoria Barahona, Madrid, 1 de marzo de 1632, AGI, Escribanía, 1024b.

${ }^{79}$ Memorial de Francisco de Vitoria Barahona, Madrid, 2 de agosto de 1634, AGI, Escribanía, 1024b.

${ }^{80}$ Informe de Hernando de Valencia, Lima, 14 de junio de 1632, AGI, Lima, 161.

${ }^{81}$ Valle Pavón 2003: 48; Schell 1991: 22, 191-192. 
se reducían los envíos a la Península y, consecuentemente, aumentaban las presiones. ${ }^{82}$ Además, no importaba cuánto se gastara en defensa, la correspondencia del virrey es ampliamente reveladora de que los holandeses estaban ganando la guerra psicológica. Los comerciantes mostraban miedo y desánimo a la hora de embarcar sus cargas pues estaban conscientes de la terrible situación de inseguridad que había en la mar y procuraban estar al tanto de todos los avistamientos de enemigos que ocurrían en los litorales e islas de manera regular. Por ello, Cerralbo insistía al rey en lo necesario que era consagrar el proyecto, ya discutido antes, de formar una armada que patrullara las Islas de Barlovento. ${ }^{83}$

Considerando todo ello, era lógico que los novohispanos se inclinaran hacia el comercio por el Pacífico. Un pasaje del diario de Suardo revela igualmente la preocupación que estos sentían ante la incertidumbre de la llegada con bien del Galeón de Manila a Acapulco, ${ }^{84}$ así como la atención que se prestaba a ello desde Lima:

A 21 de agosto de 1632, por cartas que trujo el navío de Jorge de Andrada, que tocó en Paita y vino de Nicaragua, costa de la Nueva Espańa, se supo cómo, hasta 22 de abril de este año, que no habían llegado a el puerto de Acapulco las naos que se aguardaban de Filipinas, con que todo el comercio de aquel reino quedaba suspenso y con mucho cuidado. ${ }^{85}$

Las tensiones aumentaron cuando se avistaron enemigos en las costas de Nueva Galicia, para lo cual el virrey acordó con el Consulado de México financiar que varias embarcaciones salieran a la mar para

82 Calderón 2005: 539.

${ }^{83}$ Carta del virrey marqués de Cerralbo, México, 11 de mayo de 1632, AGI, México, 31, n. 8; México, 7 de octubre de 1632, AGI, México, 31, n. 9.

${ }^{84}$ Había muerto el castellano Antonio de Figueroa, enviado por Felipe IV para resguardar el puerto. En su lugar, Cerralbo nombró a Juan Rodríguez de Barrientos, afecto suyo, con lo que recuperaba el control del puerto (Carta del virrey marqués de Cerralbo, 2 de mayo de 1632, AGI, México, 31, n. 4). El virrey no dejaría de insistir hasta el final de su gestión lo importante que era que los virreyes recuperaran la facultad de nombrar a la gente del cargo (Carta del virrey marqués de Cerralbo, México, 18 de diciembre de 1634, AGI, México, 31, n. 28). Probablemente lo hacía porque de esa manera podría continuar sus negocios turbios.

${ }^{85}$ Suardo 1935: 193. 
encontrarse con las naos de Filipinas y resguardarlas hasta Acapulco. ${ }^{86} \mathrm{~A}$ pesar de que el Consulado de Lima había escrito un nuevo memorial en junio, donde repetía prácticamente lo mismo que en el del año anterior, ${ }^{87}$ los comerciantes dispusieron que se enviara el navío de permiso. Este se haría a la vela el 31 de diciembre de $1632^{88}$ y sería el último que lo haría legalmente durante aquel siglo.

\section{LOS ÚlTimos DETERMinANTES PARA LA PROHIBICIÓN (I633-I634)}

El navío, de nombre San Ambrosio, alcanzó Acapulco en marzo de 1633 y fue retenido, pues se comprobó que había transportado ilegalmente 1,700 cargas de cacao. Este era un caso excepcional pues, a pesar de que era por todos sabido el contrabando que se había practicado por esa ruta, llevaba tiempo que no se aplicaba oficialmente la ley. ${ }^{89}$

$\mathrm{Al}$ otro lado del virreinato, en el Caribe, la expedición del marqués de Cadereita y el almirante portugués, Lope de Hoces, enviada por Olivares para rescatar la isla de San Martín, cumplió su misión en junio. Un par de meses más tarde, Benito Arias Montano recuperó Unare, pero los holandeses tomaron Trujillo, se extendieron por la costa de Guayana ${ }^{90} \mathrm{y}$ propinaron un gran ataque de rapiña al puerto de Campeche en agosto. ${ }^{91}$ Siendo fiel testigo durante ese verano del estado en que se encontraba el Caribe, Lope de Hoces expresó con ironía: «Pues habiendo pasaje tan

${ }^{86}$ Carta del virrey marqués de Cerralbo, México, 7 de octubre de 1632, AGI, México, 31, n. 9.

${ }^{87}$ Rodríguez Vicente 1960: 252.

${ }^{88}$ Suardo 1935: 207.

${ }^{89}$ Sales Colín 2000: 115. En 1633, se ordenó que los informadores, a quienes hasta ese momento les correspondía la tercera parte de los bienes confiscados, no se les entregara en mercancía su parte de la ganancia sino en dinero (Borah 1954: 127).

${ }^{90}$ Amadori 2011: 361, 386, 389; Brown y Elliott 1988: 173; Israel 1990: 289.

${ }^{91}$ Informaciones de Francisco Maldonado, 2 de junio de 1634, AGI, México, 238, n. 12. En el escenario europeo, en abril se había formado la Liga Heilbron entre las Provincias Unidas y Suecia. Las fuerzas imperiales fueron derrotadas en el mes de julio en HeissischOldendorf y Steinau, pero el duque de Feria consiguió tres victorias importantes en Alemania durante los próximos meses contra la Liga protestante y los suecos (Bonney 2002: 191). 
franco de Sanlúcar a Nueva España, es bien sabido que la fuente perenne del Potosí deje Castilla para correr a China». ${ }^{92}$

Las afirmaciones del almirante coincidían con las que expresaba, en octubre, un vecino de Manila llamado Jerónimo de Fuentes Cortés. Este escribía al Consejo que el archipiélago se encontraba en gran desorden gracias a la llegada de agentes novohispanos y peruanos con tanta plata —estimaba entre 3 y 4 millones de pesos- que habían absorbido por completo las mercancías asiáticas para cumplir con la orden de sus jefes, quienes exigían el envío de sus ganancias a cambio de otorgarles el 10\% a los factores. Ello había provocado un encarecimiento de los productos en Manila, además de que era muestra fehaciente de que los americanos no respetaban las cédulas. Por ende, Fuentes solicitaba autorización para que los manileños enviaran 500 mil pesos en mercaderías a México para volver con un millón en plata sin ninguna intermediación de los americanos. Finalmente, pedía que los gobernadores de Filipinas fueran enviados desde el Perú y no México, pues allí se acostumbraba sobornarlos y tejer relaciones de amistad con ellos. ${ }^{93}$

Pero ciertos hechos que ocurrieron en Perú tendrían consecuencias trascendentales. Fue hasta estos momentos de 1633 que se sintieron en Lima los efectos de los navíos enviados a Acapulco en 1629 que habían sido embargados por el virrey: el banquero Juan de la Cueva perdió esas embarcaciones, las ganancias habían tardado demasiado en llegar y, cuando finalmente llegaron, los comerciantes fueron acusados de contrabandistas, no se pudieron pagar las obligaciones contraídas, y hasta el virrey Chinchón se encolerizó con el banquero. Ello constituyó un duro golpe a los mercaderes peruanos, más tomando en cuenta que todavía se sufrían los efectos de la guerra entre «vicuñas» (castellanos, manchegos, andaluces y otros) y vascongados en Potosí, y que el suministro de azogue escaseaba más que nunca. Con ello quebró el depositario general y el banco público más importante — que era el de Cueva - sufrió una gran contracción. De tal suerte, en un acuerdo general de hacienda, los

\footnotetext{
92 Citado en Valdés Lakowsky 1987: 123.

${ }^{93}$ Suárez 2015: 120.
} 
miembros del Consulado decidieron cancelar el navío de permiso que iba todos los años a Nueva España. En realidad, la decisión fue tomada por los 50 comerciantes más ricos y poderosos de Lima, pues se opusieron, tanto los comerciantes medios, como el virrey Chinchón, el cual ya era partidario de enviar, no uno, sino dos navíos anuales. ${ }^{94}$

La crisis de azogue estaba en su cúspide. Huancavelica no era capaz de abastecer la demanda de mercurio de las minas del Perú y menos de la Nueva España. En la Península también se estaba dificultando financiar la producción de Almadén y en Alemania los Fugger se declararon en bancarrota. Por ello se solicitaba el elemento a Antonio Balbi e incluso se permitía a Nueva España importarlo de China. En 1633 la situación fue tan desesperada que Chinchón pidió a Cerralbo un envío de urgencia y una real cédula confirmó que se embarcara. ${ }^{95}$ No obstante, esa era una manera de practicar el contrabando. Como si las cosas no estuvieran suficientemente mal, en 1634, la Corona, desesperada por conseguir fondos, se negó a suministrar azogue bajo los comunes créditos sencillos y comenzó a exigir el pago de las deudas que tenían atrasadas los mineros novohispanos. ${ }^{96}$ Las minas de azogue eran propiedad real, y como esta debía pagarle a los asentistas, muy frecuentemente se retrasaban los pagos ante la delicada situación por la que atravesaba. Así habían quebrado los Fugger y por la misma razón se creaba un círculo vicioso pues, si no recibían remesas de mercurio, los mineros no podían producir plata, y sin plata no podían pagar el mercurio que debían. ${ }^{97}$

Con todo y esos problemas, en la ciudad de México había motivos para festejar pues, a principios de 1634, quedó completamente liberada

${ }^{94}$ Rodríguez Vicente 1960: 246; Suárez 2015: 117-120. No obstante, Sales Colín registra que a fines de 1633 o principios de 1634 entró en Acapulco la fragata San Pedro y San Pablo, procedente de El Realejo, comprada por Jorge Rodríguez para llevar al Perú mercaderías del permiso. El autor dice que la fragata debió navegar directamente de Acapulco al Callao (Sales Colín 2000: 114).

${ }^{95}$ Castillejo Calvo 2008: 109; véase Carta del virrey marqués de Cerralbo, México, 2 de mayo de 1632, AGI, México, 31, n. 5; se puede ver que finalmente se embarca en Carta del virrey marqués de Cerralbo, México, 31 de mayo de 1634, AGI, México, 31, n. 24. 96 Israel 1990: 294-295.

${ }^{97}$ Castillejo Calvo 2008: 109; Iwasaki Cauti 1992. 
de las aguas que la habían anegado durante cinco largos años. Aunque en las obras de desagüe se habían gastado más de 1,600,000 pesos, ${ }^{98}$ ahora la ciudad esperaba volver a su antiguo esplendor y se estimaba que se podrían recaudar hasta 194 mil pesos anuales de alcabalas para la Unión de Armas. ${ }^{99}$

Para que ello se hiciera realidad había que impulsar el comercio y, en una carta que el Cabildo dirigió a Felipe IV, los regidores mostraron su postura respecto de los tres grandes ejes comerciales que manejaba el virreinato. ${ }^{100}$ En cuanto al comercio con España, expresaban que los vecinos de la ciudad habían dejado de enviar a emplear sus haciendas debido a que habían subido mucho los impuestos, de manera que no generaban suficientes ganancias, más considerando los grandes riesgos del mar y de enemigos a los que estaban expuestas, así como la posibilidad de que, lo que llegara con bien a España, pudiera ser incautado por el rey. Todo ello incitaba al contrabando o provocaba alzas en los precios, quedando los productos fuera del alcance de los consumidores. Decían que, cuarenta años atrás, llegaban entre 30 y 40 naos y, con los derechos a $7 \%$, no se embarcaba ninguna cosa fuera de registro; mientras que ahora, apenas llegaban ocho naves a media carga y los derechos, aún tan crecidos, ${ }^{101}$ no alcanzaban a montar ni la mitad de lo que montaban en aquel tiempo. Por ello, suplicaban que ningún año dejara de enviarse flota, la disminución de los impuestos y el evitar a toda costa la incautación de las haciendas de los comerciantes pues, solo así, se volvería a engrosar la contratación, aumentarían las utilidades de la Real Hacienda y se conseguiría el bien de toda la República. En cuanto al comercio con

\footnotetext{
${ }^{98}$ Calderón 2005: 492.

99 Schell 1991: 191.

${ }^{100}$ Cerralbo no dejo de insistir al rey lo benéfico que sería aceptar a manifestación determinadas mercancías pues, de otra manera, no se les sacaba ningún provecho (Carta del virrey marqués de Cerralbo, 10 de febrero de 1634, AGI, México, 31, n. 19). En Perú, el virrey Chinchón respetó la determinación de la Corona de no aceptar mercancías a manifestación (Rodríguez Vicente 1960: 278-279) pero en Nueva España, Cerralbo lo siguió haciendo varias veces, por lo que fue reprendido por Felipe IV.

${ }^{101}$ Para estos momentos ya se estaba considerando cobrar 32\% de avería (Consulta de junta particular sobre la avería, Madrid, 24 de abril de 1634, AGI, Indiferente, 758).
} 
Filipinas, exclamaban que no era justo que los vecinos del archipiélago fueran los únicos a los que se les permitiera emplear en los productos asiáticos, ${ }^{102}$ los cuales habían hecho estanco en la ciudad de México con tres factores que, aprovechando la falta de géneros europeos por las causas expuestas en el punto anterior, alzaban los precios a su antojo, propiciando nuevamente el contrabando. De tal suerte, los regidores pedían libertad comercial, tanto con Filipinas como con el Perú, o al menos proponían que se probara durante dos años para demostrar los grandes beneficios que ello traería a la Real Hacienda y que no disminuiría el comercio con España, como argüían los sevillanos. ${ }^{103}$

Tomando en cuenta ese sentir de los mexicanos y, en vista de que los limeños no habían enviado el navío reglamentario el año anterior, probablemente se explica lo sospechoso que fue el apresto en Acapulco de un navío, llamado La Concepción, para que viajara a Panamá y después al Callao, de donde era oriundo. Este había traído armas de Panamá para que fueran enviadas a Filipinas. ${ }^{104}$ Aunque la documentación no lo registra, tenía toda la pinta de estar destinado a contrabandear. ${ }^{105}$

${ }^{102}$ Más considerando que los mexicanos estaban más expuestos a los socorros, empréstitos, donativos, servicios e impuestos.

${ }^{103}$ Carta del cabildo de México, México, 7 de febrero de 1634, AGI, México, 317. Las respuestas del rey y el Consejo a esas peticiones fueron todas negativas. Por esas fechas, en Sevilla y Madrid se estaba negociando un nuevo asiento de avería en que probablemente los sevillanos solicitaron nuevamente restricciones al comercio por el Pacífico (Consulta del Consejo de Indias, Madrid, 4 de abril de 1634, AGI, Indiferente, 758).

${ }^{104}$ Para este año, las Filipinas se encontraban igualmente en una situación muy delicada de defensa ante el acecho holandés y el de los otros enemigos de la zona (Carta del virrey marqués de Cerralbo, México, 25 de marzo de 1634, AGI, México, 31, n. 21).

${ }^{105}$ Probablemente se trataba del mismo al que Cerralbo hizo alusión en una de sus cartas en donde decía haber enviado 500 quintales de azogue al virrey del Perú «con una fragata que estaba de partida y no es capaz de más carga, ni aun me atreviera a enviar más cantidad habiendo perdido la esperanza de ver la flota de este reino en él antes del tiempo ordinario»( Carta del virrey marqués de Cerralbo, México, 31 de mayo de 1634, AGI, México, 31, n. 24, ff. 1-2). Existen numerosos reportes de que se practicaba el contrabando tanto en los navíos de aviso que iban a advertir de la presencia de enemigos, como en aquellos contratados por la Corona para transportar artillería a otros puertos del litoral pacífico. También aquellas que viajaban «vacías» a Sonsonate para ser «aderezadas», así como los transportes de personas desde Acapulco a Centroamérica (Sales Colín 2000: 115-116). 
Por su parte, los del Consulado limeño continuaban negados a enviar navío a Acapulco por los reveses que habían sufrido anteriormente. Todavía más cuando, en agosto de 1634, el fraile Roque de Saona escribió un memorial dirigido a Felipe IV en donde exhibía algunas de las maniobras que envolvían aquellos negocios. Denunciaba al conde de Chinchón de obtener entre 12 y 13 mil pesos de los navíos de permiso que navegaban hacia Nicaragua o Acapulco, además de que los forzaba a traer brea que ingresaba a precios muy altos a los almacenes reales. A los mercaderes Simón Cascos de Quirós y Jorge Rodríguez de Lisboa los acusaba de haber pagado 12 mil y 14 mil pesos, respectivamente, para viajar a México y a su regreso haber ingresado por los jardines del palacio de Lima 70 cajas de ropa prohibida de China. De igual manera, escribía que, en 1629, el banquero Cueva le había prestado a su hermano Esteban 50 mil pesos para llevarlos a emplear a México en contrabando, y por no haber regresado a tiempo, lo había forzado a pagarle $80 \%$ por cada año de retraso. Por último, para evitar una quiebra por las demandas, el banquero había pedido a Chinchón que depositase a su banco la plata que solía manejar el depositario general, provocando a cambio la quiebra de este y, a partir de entonces, habían ingresado más de 250 mil pesos al banco por ese concepto, de los cuales 90 mil eran para pagar la deuda del virrey y los intereses generados. ${ }^{106}$

Casi al mismo tiempo que en Lima escribía su memorial el fraile, en Madrid volvía a entrar en escena el arbitrista Vitoria Barahona, y esta vez lograría un cambio. El memorial que había elevado al Consejo dos años antes había sido remitido a una junta especial que, como se mencionó, había debatido minuciosamente los contenidos. Ahora Vitoria Barahona entregaba un nuevo memorial en el que apoyaba mucho más decididamente una de las posturas y rebatía los cuestionamientos de la junta.

Comenzaba exponiendo tres puntos principales: primero, que todo el comercio trasatlántico se había reducido gracias al trato que tenían las Indias con Filipinas, del cual estaban tan abastecidas, que ya no tenían necesidad de comunicación con Castilla. Además, las manufacturas 
novohispanas se exportaban a todo el continente tal y como lo hacían los vinos peruanos, a pesar de que esto último estaba prohibido. El segundo punto explicaba la depresión de la industria castellana derivada del primero, así como el declive de la Carrera de Indias, que veinte años atrás solía enviar hasta sesenta naos a Nueva Espańa y veinte a Tierra Firme, mientras que ahora no rebasaban las veinte y las seis, respectivamente. En tercer lugar, trataba la reducción de las rentas de la Corona, pues al carecer de intercambios habían caído dramáticamente y las averías habían aumentado de $6.5 \%$ a 30 o $40 \%$, consumiendo toda posible ganancia que se pudiera hacer. Ello incapacitaba a los sevillanos a subsanar los gastos invertidos, por lo que no les quedaba más que recurrir al contrabando. Tal era la situación atlántica, mientras que en el Pacífico se traficaba diez veces la cantidad permitida: las naos de Filipinas, de 400 mil de licencia, llevaban cuatro millones que volvían con diez millones en mercancías, cobrándose de derechos, como máximo, respecto de los 400 mil del permiso. Asimismo, ocurría con la que iba de Perú a Nueva España, teniendo licencia de 200 mil, embarcaba dos millones. De tal suerte, esgrimía que el único remedio efectivo sería extinguir por completo la ruta Callao-Acapulco. ${ }^{107}$

En la segunda parte del memorial respondía a las cuestiones principales que le había señalado la junta. Primero se le había cuestionado si cortar el comercio entre Perú y Nueva España no afligiría a los americanos, los cuales eran vasallos igualmente. Vitoria Barahona alegaba que los daños eran tan grandes que lo debían aceptar, al fin que prácticamente todo lo que se llevaba por esa ruta era ilegal. A la propuesta de reducir el tamaño de las naos que se enviaban a Filipinas a lo justo para que no cupieran mercancías de sobra, la junta había argumentado que se necesitaban naos de gran porte para resistir las tormentas del Pacífico, como las que se utilizaban de 1,200 o 1,400 toneladas. Vitoria Barahona respondió que los expertos sostenían que el tamaño para realizar la ruta de forma más rápida y segura era con naos de 400 o 500 toneladas. También sugería que, para llevar a cabo la ejecución, se debía enviar desde Espańa una persona

${ }^{107}$ Memorial de Francisco de Vitoria Barahona, Madrid, 2 de agosto de 1634, AGI, Escribanía, 1024b. 
de gran autoridad con inhibición del virrey y la Audiencia; y con tiempo limitado para que, después de ejecutado, volviese a la Península a dar parte. A este respecto, la junta temía que surgieran las clásicas competencias de poder entre aquella persona y el virrey, entorpeciendo su accionar. Pero Vitoria Barahona declaraba, con razón, que aquellas diligencias habían sido encomendadas a todos los virreyes pasados y no habían cumplido, además que, de cualquier manera, el virrey tenía tantas ocupaciones que no podría llevarlo a cabo personalmente y tendría que encomendarle a alguien la tarea, favoreciendo sus intereses. De tal suerte, era mejor elegir a una persona impecable que no fuera a otra cosa más que a ello. ${ }^{108}$ Veintidós días después, el Consejo de Indias presentaba su veredicto:

supuesto que no han bastado las prevenciones que se han hecho para refrenar la codicia de los que se debieran contentar con lo que les está permitido [...], es preciso y conveniente, para desarraigar de una vez tan perniciosa consecuencia, alzar y quitar de todo punto la dicha permisión porque de otra manera se tiene por incurable este mal abuso. ${ }^{109}$

No obstante, advertía que había que ejecutarlo delicada y paulatinamente para no crear sentimientos o rencores en los interesados. Por ello, recomendaba escribir a ambos virreyes que era una determinación temporal de cinco años, a través de los cuales deberían ir examinando e informando del modo en que lo recibían los afectados y de las conveniencias o inconveniencias que de ello fueran resultando para que entonces se tomara la resolución definitiva. Por otro lado, también accedían a minorar el porte de las naves de Filipinas a 500 toneladas la capitana y 400 la almiranta. ${ }^{110}$

En cuanto a la persona que debía investigar y resguardar que todo se cumpliese, unos consejeros preferían que cada año se eligiese a un oidor,

${ }^{108}$ También recomendaba enviar visita a todos los reinos, "principalmente a la Nueva España, donde los ánimos son tan domésticos, para que no se pueda temer ninguna de sus acciones cuando el efecto a que se va tiene tanta justificación [...], y siendo los del Perú de ánimos tan belicosos, con haber ido el contador Valencia a distintos casos, no hubo el menor rumor en su ejecución...» (Memorial de Francisco de Vitoria Barahona, Madrid, 2 de agosto de 1634, AGI, Escribanía, 1024b).

${ }^{109}$ Consulta del Consejo de Indias, Madrid, 24 de agosto de 1634, AGI, Indiferente, 758. ${ }^{110} \mathrm{Ib}$. 
con supervisión del virrey, para que se encargase de la inspección, en lugar de enviar a un visitador desde España, pues ello conllevaría mayores gastos a la Real Hacienda. No obstante, Bartolomé Morquecho ${ }^{111}$ y Juan de Palafox difirieron. El último expuso que, si había interés de alguien de la administración en que creciera el comercio con Asia, era precisamente de los virreyes, por lo que era mejor enviar a una persona desde España con la misión específica, como había sugerido Vitoria Barahona. El consejero concluía diciendo que

entretanto que V.M. no fuere servido de ajustar el desorden que en el puerto de Acapulco hay en vaciar por él los tesoros de las dos provincias, meridional y septentrional, que en tan inmensa cantidad salen a naciones extrańas y enemigas del nombre cristiano, sería imposible que vuelva a florecer el comercio de España, abundar en plata y estar unidos como conviene a aquellos vasallos con estos. ${ }^{12}$

Después de expuesta la opinión del Consejo al rey, hubo que esperar a que este tomara la última resolución. Sin duda, había muchas cuestiones en las mentes de Felipe IV y Olivares. La guerra continuaba alrededor del mundo y la monarquía estaba en juego. Los holandeses habían ocupado Curazao en agosto, la cual era una posición sumamente estratégica desde donde podrían dominar el Caribe y poner en peores aprietos de los que estaba la comunicación entre Castilla y los reinos de ultramar. ${ }^{113}$ En septiembre, las fuerzas españolas, dirigidas por el cardenal-infante, se unieron a las de Fernando de Austria y, conjuntamente, vencieron

${ }^{111}$ Este consejero tenía experiencia en Indias, pues había sido ejercido como fiscal de Panamá entre 1607 y 1612 (Amadori 2011, 204).

${ }^{112}$ Consulta del Consejo de Indias, Madrid, 24 de agosto de 1634, AGI, Indiferente, 758. La Consulta lleva las rúbricas del conde de Castrillo, presidente del Consejo, Juan de Solórzano Pereira, Bartolomé Morquecho y Juan de Palafox. Lo que se percibe en este documento es radicalmente opuesto a lo que Cayetana Álvarez de Toledo escribió en su libro: «Palafox, a quien se le solicitó explícitamente que expresara su parecer sobre este tema, rechazó los planes del conde-duque con el argumento de que levantar barreras en el comercio interamericano obstaculizaría la recuperación económica de los virreinatos, condición necesaria para la recuperación del comercio trasatlántico» (Álvarez de Toledo 2011: 82-83).

${ }^{113}$ Amadori 2011: 394; Israel 1990: 281. 
al ejército sueco-sajón en la batalla de Nördlingen. ${ }^{114}$ Pero ni el rey, ni sus ministros, fueron optimistas cuando se dieron cuenta que aquella proeza no mejoraría la situación de España pues, además del gran coste que tuvo, ${ }^{115}$ había provocado que Francia se sintiera en peligro, por lo que Luis XIII y Richelieu habían decidido unirse formalmente a la Liga Heilbron con Suecia, algunos príncipes alemanes y las Provincias Unidas, con lo cual se hacía inminente su entrada en la guerra. ${ }^{116}$ Los ministros espańoles comenzaron a calcular la cantidad de dinero que tendrían que disponer exclusivamente en el ámbito militar para afrontar el siguiente año de 1635. Las cifras superaban los ocho millones de ducados y fueron tan pavorosas que, en el Consejo de Estado, se llegó a examinar si convendría abandonar algún territorio por ser muy costosa su defensa, pero al final se decidió continuar la misma política que se había seguido durante todo el reinado: la de defender hasta el último centímetro de tierra de la monarquía. ${ }^{117}$

Si bien Felipe IV y Olivares no habían exigido nada a los mercaderes de Sevilla durante lo que iba del ańo, ${ }^{118}$ sabían que se iba a precisar de su mano durante los próximos. Para ello se los necesitaba tener prósperos y contentos, quizá había que concederles algo que llevaban denunciando por décadas y con lo que ahora parecían incluso estar de acuerdo sus homólogos limeños. Más allá, pensaban que España misma necesitaba vigorizar su industria, reavivar su comercio y lograr que las Indias volvieran a depender de ella como en el idealizado pasado glorioso. Fue justo esa coyuntura la que arrimó a que, el 23 de noviembre de 1634, Felipe IV expidiera una cédula real en la que prohibía absolutamente el comercio entre los virreinatos de Nueva España y Perú por cinco años. ${ }^{119}$

\footnotetext{
114 Bonney 2002: 53.

115 Alrededor de cuatro millones de ducados (Lynch 2007: 116).

116 Bonney 2002: 9; Lynch 2007: 116.

117 Elliott 1990: 164.

${ }_{118}$ Díaz Blanco 2012, p. 139.

${ }^{119}$ Real Cédula, Madrid, 23 de noviembre de 1634, AGI, Lima, 572, L. 21, ff. 44-45. También se hicieron mayores las penas para cualquier persona que practicase el contrabando, llegando a ser de hasta 10 años de galeras. Si estos ostentaban grados mayores, como el prior o cónsules de la Universidad de mercaderes, se estableció que se embar-
} 
Irónicamente, menos de un mes después, aún sin haber recibido la cédula de la prohibición en México, el virrey escribía una carta que probablemente reconfortaría al rey y sus ministros de haber tomado una sabia decisión: «en ninguna sazón podrá hacer menos falta lo que habrá de traer la flota [que está por venir de España], porque este reino se halla muy lleno de ropa y no falto de vinos». ${ }^{120}$

A lo largo de la primera mitad de 1635, con la entrada de Francia en la guerra y la preocupación por la pérdida de Curazao, se tomó otra medida encaminada a rescatar el tráfico trasatlántico que llevaba años de discusión: la de aprobar la creación de la Armada de Barlovento para que resguardara el Caribe. ${ }^{121}$ Para ello se designó a un nuevo virrey de Nueva Espańa con el fin de gestionar el proyecto. No extraña que el elegido haya sido el marqués de Cadereita, héroe de la guerra marítima al grado que le había valido aparecer representado en el Salón de Reinos del Palacio del Buen Retiro. Asimismo, se eligió a Pedro de Quiroga y Moya como visitador para garantizar el cumplimiento de la ley en el puerto de Acapulco y llevar a cabo el juicio de residencia del marqués de Cerralbo. El visitador sería tan severo que provocaría una crisis del trato y navegación entre el virreinato novohispano y las Filipinas entre los años 1635-1639. ${ }^{122} \mathrm{Al}$ archipiélago viajaron pocos navíos con poca plata durante esos años, sumado a que algunos se perdieron en el mar. Muchos de los chinos del archipiélago se retiraron y con los que permanecieron, solo aumentaron las tensiones que ya venían cargando, estallando un levantamiento que se saldó con el asesinato de unos 20 mil a manos de los españoles. Ello, lógicamente, no contribuyó al restablecimiento del comercio en los próximos años, menos considerando el acoso que provocaban los holandeses en alianza con los piratas malayo-mahometanos en la zona. ${ }^{123}$

garían todos sus bienes y se les condenaría a destierro perpetuo de todos los reinos de la monarquía (Calderón 2005: 506).

${ }^{120}$ Carta del virrey marqués de Cerralbo, México, 18 de diciembre de 1634. AGI, México, 31, n. 27.

${ }^{121}$ Alvarado Morales 1983; Sánchez 2012.

${ }^{122}$ Véase Gasch-Tomás 2015; Sales Colín 2000.

${ }^{123}$ Díaz Trechuelo 1984. 
W. S. Atwell, ha propuesto que la gran reducción de entrada de plata japonesa e hispanoamericana en China durante estos años contribuyó a la crisis interna del imperio, por lo que fue uno de los factores que precipitaron la caída de la dinastía Ming. ${ }^{124}$ Si bien el autor tan solo menciona en una nota al pie que hubo algunas restricciones al comercio virreinal, aquí se quiere resaltar, explícitamente, la trascendencia que pudo haber llegado a tener la prohibición del comercio entre Nueva España y Perú a nivel global, aunque claramente hacen falta más estudios.

\section{CONCLUSIONES}

Aquí se ha analizado la última parte de un debate que duró casi sesenta años en el que intervinieron una pluralidad de actores a través de variados niveles institucionales y en diversos lugares geográficos, a lo largo y ancho y de una monarquía que, en este sentido, podría ser denominada policéntrica. El desenlace del debate estuvo íntimamente ligado con los éxitos y fracasos de la monarquía en el ámbito internacional, así como con los vaivenes internos de cada centro. No cabe duda que la participación en la Guerra de los Treinta Años, así como la reanudación del conflicto en Flandes, fusionados con la crisis de hambre e inflación dentro de la Península, llevaron al reinado a sufrir una presión sin comparación en donde salió a relucir más que nunca el grado de autonomía que habían alcanzado los reinos de Indias y el declive del comercio trasatlántico. El robo de la flota de 1628 provocó una serie de rebotes de causa y efecto difíciles de enderezar a los que se sumaron otros imprevistos: derrotas bélicas, incautaciones a los mercaderes por parte de la Corona, la inundación de la ciudad de México, la escasez de azogue y la financiación cada vez más alta para la defensa del tráfico marino y de las posiciones estratégicas, creándose un círculo vicioso del que parecía imposible escapar. ${ }^{125}$

${ }^{124}$ Atwell 2005. Si bien sus primeras propuestas fueron duramente criticados por Von Glahn (1996), el artículo que he citado primeramente ya es una réplica bastante convincente a esas críticas.

${ }^{125}$ Si bien es cierto que el convulso siglo XVII europeo sumió a la monarquía en una crisis que permitió a los reinos indianos consolidarse e independizarse económicamente, 
Frente a tantas adversidades que enfrentaba el comercio con Europa, era lógico que los novohispanos prefiriesen el comercio con Asia y con Perú al ser más seguro y barato. Dentro de esa encrucijada, cada centro - Sevilla, Lima, México y Manila_ luchó por sus intereses, pero los dos primeros supieron acoplarlos de mejor manera con los de Madrid. A fin de cuentas, en una época donde primaba el mercantilismo, la monarquía no podía aceptar que los metales preciosos escaparan de su órbita hacia manos de infieles. El Consulado hispalense no solo parecía defender más fielmente el bienestar de Castilla, sino que también era el que la Corona tenía más cerca y del cuál ya había sacado grandes tajadas de maneras muy breves en tiempos de necesidad. Al ser inminente la entrada de Francia en la guerra, era muy probable que seguiría necesitando de él en el futuro próximo, y de acuerdo a la economía de la gracia, había que darle algo a cambio.

Es importante decir que, si bien pocos autores han tocado este tema, son varios los que mencionan la prohibición en el año de 1631. La raíz de todo ello es el emblemático trabajo de Woodrow Borah, donde no especificó ninguna fuente. La única fuente primaria que he encontrado con esa fecha es en la Politica Indiana de Solórzano Pereira. No obstante, aunque esta debería ser más que confiable al ser él mismo protagonista de los hechos, sospecho que hubo un error en su texto o en ediciones posteriores, pues no he encontrado un solo documento que siquiera insinúe su existencia. Por ello, se atendrá solo a 1634.

También se ha sacado a relucir la trascendencia que pudo haber llegado a tener aquella cédula, no solo dentro del mundo hispánico sino también fuera de él. Por último, sobra decir que el debate no comenzó donde comenzó este artículo, ni terminó con la expedición de la cédula. Por ello, hace falta estudiar igualmente a fondo el transcurso del antes y el después de la prohibición pues, al menos durante los siguientes quince años, continuó siendo un tema ávidamente discutido en diversas instancias y entornos, tal y como lo había sido antes; y los mexicanos nunca 
dejaron de reclamar su reapertura. También hace falta estudiar los efectos económicos, políticos y sociales posteriores a la prohibición, fuera de que esta se haya cumplido o no, y hasta qué grado.

\section{BIBLIOGRAFÍA}

Alonso Álvarez, Luis. 2016. «"El daño de la tierra en desfrutarla de plata” La polémica de la desmonetización en la carrera de la Mar del Sur, 1573-1593». En Yuste López, Carmen y Guadalupe Pinzón Ríos (eds.). A 500 años del hallazgo del Pacifico. La presencia novohispana en el Mar del Sur. Ciudad de México: Instituto de Investigaciones Históricas - Universidad Nacional Autónoma de México, 277-314.

Alvarado Morales, Manuel. 1983. La ciudad de México ante la fundación de la Armada de Barlovento: historia de una encrucijada (1635-1643). Ciudad de México: El Colegio de México.

Álvarez de Toledo, Cayetana. 2011. Juan de Palafox: obispo y virrey. Madrid: Marcial Pons / Centro de Estudios Europa Hispánica.

Amadori, Arrigo. 2008. «Privanza, patronazgo y fiscalidad indiana en la corte de Madrid durante el reinado de Felipe IV». Revista Complutense de Historia de América. Número 34: 63-84.

Amadori, Arrigo. 2011. Política americana y dinámicas de poder durante el valimiento del Conde-Duque de Olivares, (1621-1643). Tesis de doctorado en Historia. Madrid: Universidad Complutense de Madrid.

Atwell, William S. 2005. "Another Look at Silver Imports into China, ca. 1635-1644». Journal of World History, Número 16, 4: 467-489. https://doi. org/10.1353/jwh.2006.0013

Bonialian, Mariano Ardash. 2014. China en la América Colonial. Bienes, mercados, comercio y cultura del consumo desde México hasta Buenos Aires. Ciudad de México: Editorial Biblos.

Bonialian, Mariano Ardash. 2019. La América española: entre el Pacífico y el Atlántico. Globalización mercantil y economía politica, 1580-1840. Ciudad de México: El Colegio de México.

Bonney, Richard. 2002. The Thirty Year's War 1618-1648. Oxford: Osprey Publishing.

Borah, Woodrow. 1954. Early Colonial Trade and Navigation Between Mexico and Peru. Los Angeles: University of California Press.

Bronner, Fred. 1975. «Un agente extraordinario de Olivares para el Perú: el contador Hernando de Valencia». Boletín Del Instituto Riva-Agüero. Número 10: 29-62.

Brown, Jonathan y John H. Elliott. 1988. Un palacio para el rey, el Buen Retiro y la corte de Felipe IV. Madrid: Alianza. 
Calderón, Francisco R. 2005. Historia económica de la Nueva España en tiempo de los Austrias. México: Fondo de Cultura Económica.

Cañeque, Alejandro. 2004. The King's Living Image: the Culture and Politics of Viceregal Power in Colonial Mexico. New York: Routledge.

Casado Arboniés, Francisco J. 1986. «Los retrasos en la imposición de la Unión de Armas en México: (1629-1634)». Estudios de Historia Social y Económica de América. Número 2: 121-130.

Castillero Calvo, Alfredo. 2008. Los metales preciosos y la primera globalización. Panamá: Imprenta Editora Novo.

Chamorro, Eduardo. 1998. Felipe IV. Barcelona: Planeta.

Córdoba, Salinas de. 1631. Memorial de las historias del Nuevo Mundo Perú.

Díaz Blanco, José Manuel. 2012. Así trocaste tu gloria: Guerra y comercio colonial en la España del siglo XVII. Madrid: Marcial Pons.

Díaz Trechuelo, María Lourdes. 1984. «Las Filipinas en su aislamiento, bajo el continuo acoso». En Historia General de España y América. V: IX-2. Madrid: Rialp, 129-152.

Domínguez Ortiz, Antonio. 1998. Estudios americanistas. Madrid: Real Academia de la Historia.

Elliott, John H. 1990. España y su mundo 1500-1700. Madrid: Alianza.

García de los Arcos, María Fernanda. 1993. «La batalla de la seda». En Tortolero, Alejandro Estudios Históricos I. México: Universidad Autónoma Metropolitana, 39-68.

Gasch-Tomás, José Luis. 2015. «Mecanismos de funcionamiento institucional en el imperio hispánico. El comercio de los galeones de Manila y el Consulado de comerciantes de México en la década de 1630». Revista de Historia Jerónimo Zurita. Número 90: 55-74.

Gordon, Peter y Juan José Morales. 2017. The Silver Way. China, Spanish America and the Birth of Globalisation, 1565-1815. Pengüin Books.

Herrero Sánchez, Manuel. 2019. "Urban Republicanism and Political Representation in the Spanish Monarchy". En Albareda, Joaquim y Manuel Herrero Sánchez (eds.). Political Representation in the Ancien Régime. New York: Routledge, 319-333. https://doi.org/10.4324/9780429443855-19

Israel, Jonathan. 1980. Razas, clases sociales y vida politica en el México colonial 16101670. México: Fondo de Cultura Económica.

Israel, Jonathan. 1990. Empires and Entrepots: The Dutch, the Spanish Monarchy and the Jews, 1585-1713. London: Hambledon Press.

Iwasaki Cauti, Fernando. 1992. Extremo Oriente y Perú en el siglo XVI. Madrid: Mapfre.

Lucena Salmoral, Manuel. 1992. Piratas, bucaneros, filibusteros y corsarios en América. Madrid: Mapfre.

Lynch, John. 2007. España bajo los Austrias. Barcelona: Crítica. 
Orozco y Berra, Manuel y Antonio Espinosa de los Monteros. 1889-1911. Actas de

Cabildo de la Ciudad de México. México: Aguilar e Hijos, 50 vols.

Parker, Geoffrey. 2003. La Guerra de los Treinta Años. Madrid: Antonio Machado Libros.

Parker, Geoffrey (ed.). 2006. La crisis de la Monarquía de Felipe IV. Barcelona: Crítica.

Riva Palacio, Vicente. 1981. «Historia del virreinato (1521-1807)». En Riva Palacio, Vicente México a través de los siglos. V. IV. México: Cumbre.

Rodríguez Vicente, María Encarnación. 1960. El tribunal del Consulado de Lima en la primera mitad del siglo XVII. Madrid: Ediciones Cultura Hispánica.

Romano, Ruggiero. 1993. Coyunturas opuestas: la crisis del siglo XVII en Europa e Hispanoamérica. Ciudad de México: El Colegio de México.

Rubio Mañé, José Ignacio. 2005. El virreinato. Ciudad de México: Fondo de Cultura Económica.

Sales Colín, Oswald. 2000. El movimiento portuario de Acapulco: el protagonismo de Nueva España en la relación con Filipinas, 1587-1648. Ciudad de México: Plaza y Valdés.

Sánchez Santiró, Ernest. 2012. «La Armada de Barlovento y la fiscalidad novohispana (1636.1749)». En Alves Carrara, Angelo y Ernest Sánchez Santiró. Guerra y fiscalidad en la Iberoamérica colonial (siglos XVII-XIX). Ciudad de México: Instituto Mora / Universidade Federal Juiz de Fora, 65-90.

Schell Hoberman, Louisa. 1991. Mexico's Merchant Elite, 1590-1660. Silver, State and Society. Durham: Duke University Press.

Schurz, William L. 1918. "Mexico, Peru, and the Manila Galleon». The Hispanic American Historical Review. Número 1, 4: 389-402. https://doi. org/10.1215/00182168-1.4.389

Suardo, José Antonio. 1935. Diario de Lima (1629-1634). Edición de Rubén Vargas Ugarte. Lima: C. Vázquez.

Suárez, Margarita. 2001. Desafíos transatlánticos: mercaderes, banqueros y estado en el Perú virreinal, 1600-1700. Lima: Pontificia Universidad Católica del Perú, Instituto Riva-Agüero. https://doi.org/10.4000/books.ifea.4039

Suárez, Margarita. 2015. "Sedas, rasos y damascos: Lima y el cierre del comercio triangular con México y Manila en la primera mitad del siglo XVII». América Latina En La Historia Económica. Número 22, 2: 101-134. https://doi. org/10.18232/alhe.v22i2.591

Valdés Lakowsky, Vera. 1987. De las minas al mar. Historia de la plata mexicana en Asia: 1565-1834. Ciudad de México: Fondo de Cultura Económica.

Valle Pavón, Guillermina del. 2003. «Gestión del derecho de alcabalas y conflictos por la representación corporativa: la transformación de la normatividad electoral del Consulado de México en el siglo XVII». En Hausberger, Bernd y Antonio Ibarra (eds.). Comercio y poder en América colonial: los consulados de comerciantes, 
siglos XVII-XIX. Ciudad de México: Bibliotheca Ibero-americana, 41-72. https:// doi.org/10.31819/9783964565105-003

Valle Pavón, Guillermina del. 2005. «Los mercaderes de México y la transgresión de los límites al comercio pacífico en Nueva España, 1550-1620». Revista de Historia Económica. Número 23, 1: 213-240. https://doi.org/10.1017/ S0212610900012295

Von Glahn, Richard. 1996. «Myth and Reality of China's Seventeenth-Century Monetary Crisis». The Journal of Economic History. Número 56, 2: 429-454.

Wilson, Peter H. 2009. The Thirty Years War, Europe's Tragedy. Massachusetts: The Belknap Press of Harvard University Press. https://doi.org/10.1017/ S0022050700016508

Yun Casalilla, Bartolomé. 2019. Historia global, historia transnacional e historia de los imperios. El Atlántico, América y Europa (siglos XVI-XVIII). Zaragoza: Institución Fernando el Católico / Excma. Diputación de Zaragoza,.

Yuste López, Carmen. 2013. «De la libre contratación a las restricciones de la permissión. La andadura de los comerciantes de México en los giros iniciales con Manila, 1580-1610». En Bernabéu Albert, Salvador y Carlos Martínez Shaw (eds.). Un océano de seda y plata: el universo económico del Galeón de Manila. Sevilla: Consejo Superior de Investigaciones Científicas, 85-106.

Fecha de recepción: 21/IV/2020

Fecha de aceptación: 18/IX/2020 